\title{
Experimental model of autoimmune myosin-induced myocardium injury
}

\author{
V. I. Bobyk, D. V. Ryabenko', O. V. Sergienko', I. V. Trunina', O. M. Fedorkova, L. M.
}

Morozova, L. L. Sidorik

Institute of Molecular Biology ad Genetics NAS of Ukraine

150, Zabolotny Str., Kyiv, 03143, Ukraine

${ }^{1}$ Strazhesko Institute of Cardiology MSA of Ukraine

5 Narodnogo Opolcheniya Str.,Kyiv, 03151,Ukraine

sidorik@imbg.org.ua

Experimental model of autoimmune myosin-induced injury of BALB/c mouse myocardium, similar to human dilated cardiomyopathy (DCM), has been developed. The immunisation by myosin, purified from DCM-affected human heart initiated the following DCM-like myocardial damage: myocytolysis, cardiosclerosis, thinning of left ventricular wall, changes in cardiac actomyosin ATP-ase activity and increase of anti-myosin autoantibodies level.

Keywords: dilated cardiomyopathy, autoantibodies, myosin, myocardial damage.

Introduction. Molecular medicine is the branch of medical science which studies disorders in human organisms at the molecular level and develops the approaches to their elimination using the methods of molecular biology. The identification of structural and regulatory human genes and the investigations on regulation of their expression, as well as the studies on disorders which result in acquiring of hereditary and multifactorial diseases, comprise the scientific foundation of molecular medicine [1]. Recent decade was notable for rapid increase in investigations on molecular-genetic bases of cardiovascular diseases, which still remain the main death factor. Special attention of scientists and doctors in this country and abroad was paid to different types of cardiomyopathy,

\footnotetext{
(C)V. I. BOBYK, D. V. RYABENKO, O. V. SERGIENKO, I. V. TRUNINA,

O. M. FEDORKOVA, L. M. MOROZOVA, L. L. SIDORIK, 2007
}

among which the hardest and the most common one is dilated cardiomyopathy (DCM). The reasons which lead to acquiring and development of this disease have not been studied enough, thus, the priority in this research is set on revealing molecular disorders of myocardium functioning.

World Health Organization provides definition for dilated cardiomyopathy as myocardial disease of unknown ethiology that is characterized by enlargement of left heart ventricle (or both), decrease of myocardium shortening and development of heart failure. It has been proposed that the cardio-specific autoimmunity, mitochondrial disfunction and apoptotic death of cardiomyocytes with subsequent development of collagenosis/fibrosis of heart muscle could be characteristic features of such pathology. DCM is considered to be one of the main indices for heart transplantation. 
The disease may be triggered by both different types of stress and infection injury of myocardium by various viruses, bacteria, protozoa, metabolic disorders in oxidation of fatty acids, disorders in mitochondrial oxidative phosphorylation of respiratory chain, toxic effect of alcohol, heavy metals, etc [1-4]. The mechanisms of further progression of the disease are subject to additional investigations.

Nowadays the presence of autoimmune processes in development of heart diseases is doubtless [5-6]. Patients' blood sera samples were shown to have the increased level of auto-antibodies against a series of antigens, in particular, to the proteins involved in heart muscle shortening, basic structural proteins (actin, myosin, C-protein), and regulatory proteins (tropomyosin and the troponins) [7-9]. It has been revealed also that development of DCM is accompanied by the changes in functioning of anti-stress proteins, i.e. molecular chaperons, the consequence of which is incorrect protein folding of various subcellular compartments of cardiomyocyte, which, in its turn, assists in accumulating of defective proteins. The latter are known to be the stress signal for cardiomyocyte to activate stress-induced apoptotic pathways, responsible for survival or death of cardiomyocyte [10-13]. The study on molecular and cell mechanisms of DCM is complicated due to the absence of adequate animal models for development of this pathology. There are only several transgenic models, which do not provide the complete picture of human disease, unfortunately [14]. The development of myosin-induced system of DCM-like pathology in animals is of great importance in order to understand the processes which take place in human organism at different stages of development of the disease. The availability of such a model will allow studying molecular and cellular specificities of the aforementioned processes, their succession, investigating molecular-structural changes in cardiomyocytes and in their components, as well as modelling and tracing the effect of different medicines and biologically active substances.

Materials and Methods. The preparations of myosin were purified from biopsy material of the left aortic ventricle of the patient who died of DCM (DCM injured ventricle myosin, DVM), a patient who died in an accident (normal ventricle myosin, NVM), and actomyosin obtained from mouse heart using the method [15]. Purity of the preparations obtained was analyzed using gel-electrophoresis in denaturation conditions according to Leammli method [16]. Autoantibodies directed against obtained proteins were detected in patients' blood sera using ELISA method [17]. The concentration of protein was determined according to method of Bradford [18]. Myosin ATPase activity was analyzed at $37^{\circ} \mathrm{C}$ for $5 \mathrm{~min}$ in the medium containing $60 \mathrm{mM} \mathrm{KCl}, 5 \mathrm{mM} \mathrm{MgCl}, 10 \mathrm{mM}$ imidazole, $\mathrm{pH}$ 7.0, $0.25 \mathrm{mM}$ ATP; $100 \mathrm{MM} \mathrm{CaCl}_{2}$ $\left(\mathrm{Ca}^{2+}\right.$-medium) or $1 \mathrm{mM}$ of ethylene glycol-bis(2-amino ethyl ether) N,N-tetra acetic acid (EGTA-medium). Reaction was terminated by adding $\mathrm{HClO}_{4}$ to final concentration of $0.3 \mathrm{M}$. ATPase activity was assessed by the amount of chipped-off non-organic phosphate according to the method described in [19]. Male mice of $\mathrm{BALB} / \mathrm{c}$ line of 12-16 weeks old were immunised with complete Freund's adjuvant emulsion (CFA) and various myosin preparations or the physiological solution. The mice were introduced with $0.2 \mathrm{ml}$ protein emulsion in the concentration of $2 \mathrm{mg} / \mathrm{ml}$ subcutaneously. In two weeks mice were immunised once more with half of the initial dose. Following the set terms, the mice were decapitated using light ether anaesthesia, and blood serum and hearts were obtained with the purpose of using in further histological research. Material was stored in $10 \%$ formalin solution in phosphate buffer, $\mathrm{pH} 7.4$, for 24 hours. Later on, the material was dehydrated according to the general scheme and poured into paraffin forms. The sections of $5 \mathrm{Mkm}$ were stained with haematoxylin and eosin according to Van Hison's method (haematoxylin - the basic fuchsine of picric acid, BFP). To study the shortening of cardiomyocytes apparatus the method of polarization microscopy was applied. The types of injury and the degree of contracture changes of cardiomyocytes were assessed on the basis of the set criteria, proposed by Cellarius [20].

Light microscope Biolam LOMO (200x, Russia) and Axioplan microscope (USA) were used for microscopic investigations. At least 30 random myocardium regions were subject to morphometric evaluation [21].

To determine the thickness of mice left aortic ventricle the material was stored in Buen's solution at 


\section{Table 1}

The level of autoantibodies against self-cardiac myosin in mice sera, immunised with preparations of human myosin at different stages of experiment (dilution 1:540)

\begin{tabular}{c|c|c|c|c}
\hline \multirow{2}{*}{ Antigen } & \multicolumn{4}{|c}{ Days after immunisation start } \\
\cline { 2 - 5 } & 14 & 21 & 52 & 120 \\
\hline $\begin{array}{c}\text { Normal ventricle } \\
\text { myosin }\end{array}$ & 0.344 & 0.149 & 0.330 & 0.292 \\
$\begin{array}{c}\text { DCM injured ventricle } \\
\text { myosin }\end{array}$ & 0.328 & 0.455 & 0.398 & 0.585 \\
$\begin{array}{c}\text { Complete Freund's } \\
\text { adjuvant }\end{array}$ & 0.097 & 0.027 & 0.032 & 0.028 \\
\hline
\end{tabular}

room temperature for 24 hours, before pouring into paraffin it was stored in $70 \%$ ethanol solution. The block of 4-5 mm thick was cut of central heart area, perpendicularly to anatomical axis of the heart. Performing paraffin section cuts, the blocks were put the thickest side up to the section surface. Consecutive sections of 4-5 $\mathrm{mkm}$ were stained with haematoxylin and eosin. The system for image capturing consisted of composite video-in, video card, PC, and ImagePro software. Haematoxylin- and eosin-stained sections were filmed. Every sample had 10 visual fields randomly selected for investigation. Standard OMOU42 visual scale (ГОСТ 7513-75) was used for space calibration, in accordance to manufacturer's recommendations. Internal and external boarders of left aortic ventricle were drawn manually. Measurements software was used for parameter measuring and the mean of 10 measurements was calculated.

Results and Discussion. The increase in the level of autoantibodies directed against self-antigens is considered to be one of the first signs of development of autoimmune processes. A small level of autoantibodies in organism is present with the purpose of utilization of necrotized cells and their components, however, this level is controllable and can not exceed certain level. In case of increase in the antibodies level as a result of acute infectious disease, when general destruction of cells takes place, compensatory mechanisms of immune system maintain the levels at their norm for a short time. Otherwise, autoimmune disease starts its development.

Nowadays there are three basic criteria which determine the disease to be of autoimmune nature: direct evidences (appear at transmission of pathologic antibodies or pathologic T-lymphocytes from the patient to an animal), indirect evidences (are based on induction of autoimmune disease in laboratory animals), and side evidences (as a consequence of clinical characteristics of the disease) [22].

Direct evidences are proven to be the most accurate for determining the autoimmune disease ethiology yet the cases of transmitting the autoimmune disease to laboratory animals or people via pathologic antibodies are rare.

The most often are the cases of applying indirect evidences to determine the nature of autoimmune disease. For this purpose, in the beginning it is necessary to identify target autoantigen against which constant increased immune response of the patient's organism is directed. Later on, this antigen is isolated from animal tissues or post-mortem material (if there is such possibility) and then experimental immunisation is performed using this antigen. It is noteworthy that autoimmune disease of humans usually involves several antigens. The mentioned antigen is a so called 'disease-starting' one as well as those that enter the blood stream after primary injury of the tissue. At present, DCM is viewed as autoimmune organ-specific injury of myocardium. Autoimmune reactions of cardiac myosin isoform were demonstrated in both clinical and experimental researches [23, 24]. Immunisation of genetically predisposed mice using cardiac myosin was shown to result in development of autoimmune myocardium and the appearance of cardiospecific anti-myosin antibodies $[25,26]$. We have determined that mice of BALB/c line were more sensitive to introduction of cardiac myosin than of any other line.

Table 1 presents the data on immune-enzymatic determination of the autoantibodies levels directed against mice cardiac myosin, revealed in sera of model mice immunised by human myosin preparations on different days after immunisation. All sera contain significant level of autoantibodies directed against mice cardiac myosin throughout the experiment duration and the immune response to DVM and NVM shows different dynamics (Table 1) which is considered to be the characteristic feature of autoimmunity progression, induced by immunisation using the protein investigated. 
Table 2

Relative volume (\%) of cardiomyocytes with different types of injuries in mice myocardia on the $21^{\text {st }}$ day after immunisation with human cardiac

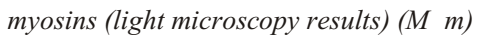

\begin{tabular}{c|c|c|c|c}
\hline \multirow{2}{*}{ Antigen } & \multicolumn{4}{|c}{ Type of cardiomyocytes damage } \\
\cline { 2 - 5 } & $\mathrm{C}$ & $\mathrm{RC}$ & $\mathrm{LC}$ & $\mathrm{M}$ \\
\hline $\begin{array}{c}\text { Complete Freund's } \\
\text { adjuvant }\end{array}$ & $1.32 \pm 0.39$ & $0.00 \pm 0.00$ & $0.00 \pm 0.00$ & $0.12 \pm 0.09$ \\
$\begin{array}{c}\text { Normal ventricle myosin } \\
\text { DCM injured ventricle } \\
\text { myosin }\end{array}$ & $3.36 \pm 0.44^{1}$ & $0.44 \pm 0.17^{1,2}$ & $0.24 \pm 0.12^{1,2}$ & $0.63 \pm 0.21^{1,2}$ \\
\hline
\end{tabular}

Note: ${ }^{1}$ - significant difference from similar indices in CFA group $(\mathrm{p}<0.001){ }^{2}$ - significant difference from similar indices in DVM ( $\left.<0.05\right)$; $\mathrm{C}-$ segmental contracture injuries of cardiomyocytes; RC - resorption of contractures; LC - local cardiosclerosis; M - myocytolysis of cardiomyocytes.

Table 3

Relative volume (\%) occupied by cardiomyocytes with different types of injury in mice myocardium after immunisation of myosin purified from

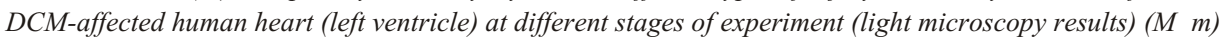

\begin{tabular}{c|c|c|c|c|c}
\hline \multirow{2}{*}{ Antigen } & \multirow{2}{*}{ Days } & \multicolumn{4}{c}{ Types of cardiomyocyte injuries } \\
\cline { 3 - 6 } & 14 & $1.12 \pm 0.29$ & $0.24 \pm 0.12^{2}$ & LC & M \\
\hline \multirow{2}{*}{$\begin{array}{c}\text { DCM injured } \\
\text { ventricle myosin }\end{array}$} & 21 & $2.32 \pm 0.39^{1}$ & $1.36 \pm 0.34^{1,2}$ & $0.90 \pm 0.00$ & $1.24 \pm 0.31^{2}$ \\
& 52 & $2.48 \pm 0.41^{1,2}$ & $1.68 \pm 0.34^{1,2}$ & $2.64 \pm 0.53^{1,2}$ & $6.76 \pm 0.64^{1,2}$ \\
& 120 & $5.16 \pm 0.69^{1,2}$ & $1.12 \pm 0.36^{1,2}$ & $1.12 \pm 0.32^{1,2}$ & $14.0 \pm 1.09^{1,2}$ \\
Complete Freund's & 14 & $1.40 \pm 0.39$ & $0.00 \pm 0.00$ & $0.00 \pm 0.00$ & $0.00 \pm 0.00$ \\
adjuvant & 21 & $1.32 \pm 0.39$ & $0.00 \pm 0.00$ & $0.00 \pm 0.00$ & $0.12 \pm 0.09$ \\
& 52 & $0.80 \pm 0.25$ & $0.08 \pm 0.08$ & $0.00 \pm 0.00$ & $0.00 \pm 0.00$ \\
& 120 & $0.68 \pm 0.22$ & $0.00 \pm 0.00$ & $0.00 \pm 0.00$ & $0.04 \pm 0.04$ \\
\hline
\end{tabular}

Note: ${ }^{1}$ - significant difference from similar indices at first stage of experiment, 14 days $(\mathrm{p}<0.01) ;{ }^{2}$ - significant difference from similar indices in $\mathrm{CFA}$ $(\mathrm{p}<0.01)$; $\mathrm{C}$ - segmental contracture injuries of cardiomyocytes; RC - resorption of contractures; LC - local cardiosclerosis; M - myocytolysis of cardiomyocytes.

The protein, isolated from the sick organ, is considered to be the autoantigen if the immunisation of animals with it causes similar disease or leads to analogous pathomorphologic changes [22].

Immunisation with DVM resulted in microcircular changes in myocardium of mice, i.e. stases, hyperaemia, aggregation of erythrocytes, swelling of arteries, partially-blown perivascular syndrome fibrosis. Segment contractures of $1^{\text {st }}-3^{\text {rd }}$ degrees are visible, the part of which is caused by necrosis, resorption, and scar formation. The number of fibroblasts, fibre component, and of belting cells with degranulation increases. Myocytolysis of cardiomyocytes as a result of direct effect of antigen is more frequent than segmental contractures. There are cases of hypertrophy of some groups of cardiomyocytes and of cells having several nuclei and increased volume of sarcoplasm. General picture is very similar to histological investigation of human myocardium, injured with DCM.

Immunisation with NVM results in the same microcircular changes. Besides, there were no cases of swelling and injury of arteries and arterioles detected and perivascular swelling was detected to be insignificant. Stromal reaction was not present as well. Belt cells were not numerous, with no degranulation. Contractural damaging of cardiomyocytes of $1^{\text {st }}-3^{\text {rd }}$ degrees were revealed.

Table 2 presents the calculations of relative volume, occupied by cardiomyocytes of different types of injuries. 


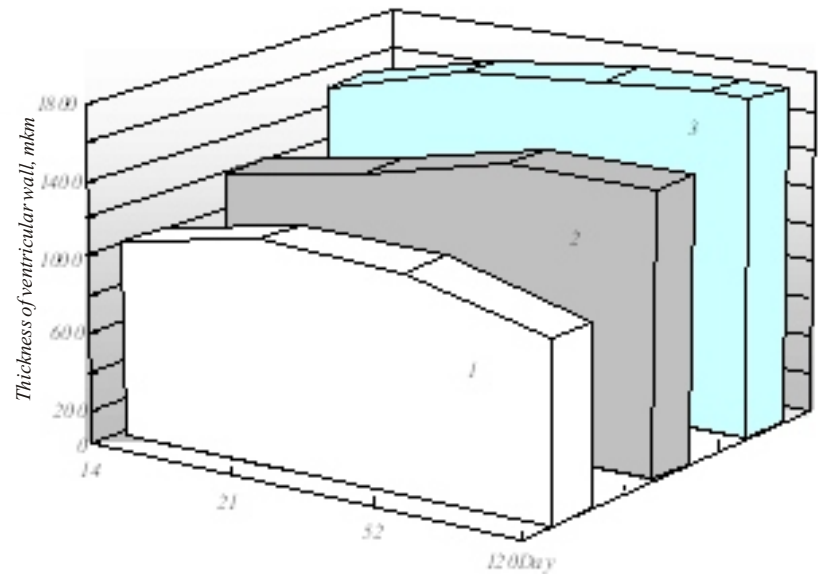

Thickness of left ventricular wall of BALB/c line mice after immunisation with myosin, purified from left ventricle of normal (2) and DMC-affected (1) hearts, and (3) after immunisation with CFA (negative control).

The data presented show that on the twenty-first day, the number of injuries was significant at immunisation with all types of myosins, however, the highest injury of cardiomyocytes was observed at DVM immunisation. The number of some types of injuries varied significantly from the number at NVM and PAT immunisation. A series of interesting results were acquired during long-term immunisation of mice with DVM. Table 3 presents the calculations of cardiomyocyte injuries during long-term DVM immunisation. The number of some cardiomyocyte injuries increases and reaches its maximum on the $52^{\text {nd }}$ day and then the number of them decreases on the $120^{\text {th }}$ day, while the number of some of them increases and reaches its maximum on the $120^{\text {th }}$ day.

Thus, relative number of cardiomyocytes with myocytolysis increases rapidly on the $52^{\text {nd }}$ day comparing to the day of initial immunisation and decreases slightly on the $120^{\text {th }}$ day, while BFP contribution is insignificant.

One of the specific features of human DCM is the thinning of left ventricular wall. Immunisation of BALB/c mice with different human myosin preparations, the thinning of left ventricular wall in regards to control was observed in experimental groups on the $14^{\text {th }}$ day after immunisation. This tendency did not change time-wise. Complete restoration of the thickness of left ventricular wall was not observed in any of the experimental groups.

The closest result was achieved in mice immunised with myosin, isolated from DCM-affected heart ventricle, which is clearly seen in Figure.
Simultaneously with the study of morphological and histological injuries taking place in cardiomyocytes at immunisation of mice with different human myosin preparations, the study on changes in ATPase activity of mice actomyosin in dynamics of experimental disease development was performed, as the ATPase activity is considered to be the indicator of muscles operation and the force of their shortening.

Table 4 presents the data proving that ATPase activity of cardiac actomyosin of laboratory animals myocardia in dynamics of pathologic development varies insignificantly, however, the value differs depending on group. Thus, ATPase activity was differed sufficiently from control (BFP-group) on the $21^{\text {st }}$ day after immunisation in all experimental groups.

Besides, NVM-groups were detected to have significantly lower ATPase activity than those of DVM, while sensitivity to $\mathrm{Ca}^{2+}$ ions was not changed. ATPase activity of mice myosin varied at early experiment stages only and reached back its initial value at later stages of DCM development.

The study on human cardiovascular diseases, in particular molecular mechanisms of their occurrence and development are of great importance and of complicated nature as well. The changes on cellular and molecular level of human heart may be determined using biopsy method only, which brings high risk and difficulties, or after the death of the patient. Therefore, the development of adequate model of the disease on laboratory animals is considered to be very important.

Experimental model of the disease has to be approximated to the one observed in humans. Table 5 shows the correlation of parameters, revealed in DCM patients, and the data obtained by us in experiments with BALB/c mice immunising them with DVM.

As it is seen from Table 5, the mice are subject to development of DCM-similar disease at immunisation of BALB/c mice with human myosin purified from DCM-affected heart. At the same time myosin purified from normal heart does not result in development of the aforementioned disease (data presented in Table).

Taking into account that the procedures of obtaining and purification of myosins were carried out at the same conditions and the preparations differed neither in isoelectric point nor mobility in polyacrylamide gel, the hypothesis that these preparations differ in post 


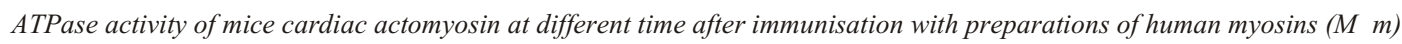

\begin{tabular}{c|c|c|c|c}
\hline \multirow{2}{*}{ Antigen } & Days & \multicolumn{3}{|c}{ Activity } \\
\cline { 3 - 5 } & 21 & $\begin{array}{c}\mathrm{Ca}^{2+}-\mathrm{medium}^{-1} \\
\mathrm{nM} \mathrm{Pi} / \mathrm{mg}^{-1} / \mathrm{min}^{-1}\end{array}$ & $\begin{array}{c}\text { EGTA-medium, } \\
\mathrm{nM} \mathrm{Pi} / \mathrm{mg}^{-1} / \mathrm{min}^{-1}\end{array}$ & Sensitivity to $\mathrm{Ca}^{2+}, \%$ \\
\hline $\begin{array}{c}\text { DCM injured ventricle } \\
\text { myosin }\end{array}$ & 52 & $190.75 \pm 2.15^{1}$ & $140.05 \pm 1.65$ & $26.56 \pm 1,69$ \\
$\begin{array}{c}\text { Normal ventricle } \\
\text { myosin }\end{array}$ & 21 & $184.65 \pm 2.45^{1}$ & $112.65 \pm 3.15^{1}$ & $31.53 \pm 2.93$ \\
$\begin{array}{c}\text { Complete } \\
\text { Freund's adjuvant }\end{array}$ & 52 & $162.97 \pm 1.28^{1}$ & $142.20 \pm 1.44$ & $23.14 \pm 0.69$ \\
\hline
\end{tabular}

Note: ${ }^{1}$ - significant difference with corresponding indices in DVM $(\mathrm{p}<0.05){ }^{2}$ - significant difference with corresponding indices in CFA ( $\left.<00.05\right)$.

The symptoms observed at experimental DCM in model mice

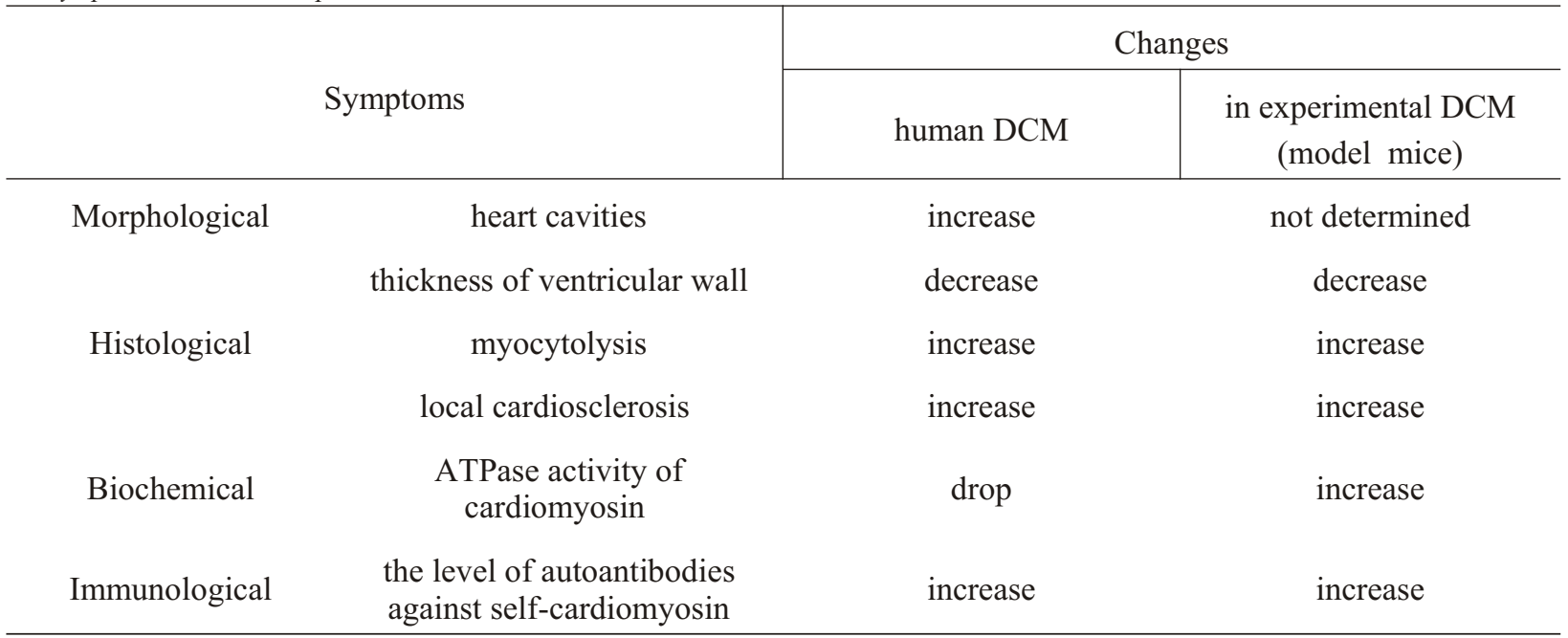

translational modifications, i.e. phosphorylation, monoand polyglycosylation, acetylation, etc or partial denaturation of myosin, resulting in exposure of new epitopes as well as in any other character of the action, has been proposed. The consequence of such modifications is incorrect folding of myosin molecule and occurrence of new antigenic determinants, due to which it is no longer recognised as 'its own' but as autoantigen.

Conclusions. Myosin purified from DCM-affected myocardium has got different immunogenic features than myosin obtained from normal myocardium.

Immunisation by myosin, purified from DCM-affected myocardium, causes significant changes in morphology of cardiomyocytes and different kinds of cardiomyocytes injury, thinning of heart wall) and ATPase activity of actomyosin, that is characteristic for human DCM development.

Immunisation of model animals by human DVM and not NVM results in induction of specific anti-myosin autoantibodies byosynthesis.

The data obtained allow proposing immunisation with heart ventricle myosin obtained from DCM-affected myocardium as a model for induced DCM-like disease in $\mathrm{BALB} / \mathrm{c}$ mice. 
В. И. Бобык, Д. В. Рябенко, О. В. Сергиенко, И. В. Трунина, О. М. Федоркова, Л. М. Морозова, Л. Л. Сидорик

Разработка экспериментальной модели аутоиммунного миозин-индуцированного повреждения миокарда

\section{Резюме}

Разработана экспериментальная модель миозин-индуцированного повреждения миокарда мымей линии $B A L B / c$, подобного дилатационной кардиомиопатии (ДКМП) человека. Показано, что лишь миозин, полученный из поврежденного ДКМП миокарда, вызывает у подопытнылх животных повреждения миокарда, характерные для ДКМП, а именно: уменьшение толщины левого желудочка сердия, миоцитолизис и кардиосклероз, снижение АТФ-ной активности, достоверное повыше ние уровня специфических аутоантител к собственному кардиомоизи нy.

Ключевые слова: дилатационная кардиомиопатия человека, аутоантитела, миозин, повреждения миокарда.

\section{REFERENCES:}

1.Keeling P. J., Tracy $S$. Link between enteroviruses and dilated cardiomyopathy: serological and molecular data // Br. Heart J.-1994.-72 (suppl. S).- S. 25-29.

2.Dale J. B., Beachey E. H. Sequence of myosin-cross-reactive epitopes of streptococcal M protein // J. Exp. Med.-1986.-164.-P. $1785-1790$

3.Cunha-Neto E., Duranti M., Gruber A., Zingales B., Messias I., Stolf N., Bellotti J., Pattaroyo M. E., Pilleggi F., Kalil J. Autoimmunity in chagas disease cardiomyopathy: biological relevance of a cardiac myosin-specific epitope cross-reactive to an immunodominant trypanosoma cruzi antigen // Proc. Nat. Acad. Sci. USA.-1995.-92.-P. 3541-3545.

4.McCall D. Alcohol and the heart // Curr. Problems. Cardiol.-1987.-27.-P. 351-408.

5.Staudt A., Schaper F., Stangl V., Plagemann A., Bohm M. Immunohistological changes in dilated cardiomyopathy induced by immunoadsorbtion therapy and subsequent immunoglobulin substitution // Circulation.-2001.-103.-P. 268-286.

6.Rose N. R., Hill S. L. Autoimmune myocarditis // Int. J. Cardiol.-1996.-54.-P. 171-175.

7.Бобык В. И., Веберов А. В., Рябенко Д. В., Дубровская Г. В., Роднин Н. В., Сидорик Л. Л. Выделение основных тканеспецифических антигенов из миокардов здоровых лиц и больных дилатационной кардиомиопатией // Биополимеры и клетка._1993.—9, № 1.-C. $63-65$.

8.Бобык В. И., Федоркова О. М., Сидорик Л. Л., Рябенко Д. В., Ковеня Т. В., Маиука Г. Х. Желудочковый и предсердный кардиальный миозин при ДКМП; сравнительное исследование иммунореактивности // Биополимеры и клетка.-1999-15, № 3.-С. $200-207$.

9.Сидорик Л. Л., Федоркова О. М., Рябенко Д. В., Бобык В. И., Данилова В. М., Трегубов В. С., Мацука Г. Х. Сравнительное исследование иммунореактивности тропонинового комплекса при дилатационной и ишемической кардиомиопатиях // Биополимеры и клетка.-2000.-16, № 1.-С. $40-45$.
10.Li Z., Menoret A., Srivastava P. Roles of heat shock proteins in antigen presentation and cross-presentation // Curr. Opin. Immunol.-2002.-14.-P. 45-51.

11.Portig I., Pankuwelt S., Maisch B. Antibodies against stress proteins in sera of patients with dilated cardiomyopathy // J. Mol. Cell Cardiol.—1997.-29.-P. 2245-2251.

12.Fink A. I. Chaperon-mediated protein folding // Physiol. Revs.-1999.-79.-P. 185-192.

13.Apoptosis, and myocardial injury // Circulation. - 2002.-105.-P. 2899-2904

14.Arber S., Hunter J. J., Ross J., Hongo M., Sansig G., Borg J., Perriard J. C., Chlen K. R., Caroni H. MLP-deficiant mice exhibit a disruption of cardiac cytoarchitectural organization, dilated cardiomyopathy, and heart failure // Cell.-1997.-88.-P. 393-403.

15.Margossian $S$. Reversible dissotiation of dog cardiac myosin regulatory light chain 2 and its influence on ATP hydrolysis // J. Biol. Chem.-1985.-260.-P. 13747-13754.

16.Laemmli $U$. Cleavage of structural proteins during the assembly of the bacteriophage T4 // Nature.-1970.—227.-P. 680—685.

17.Matsiota P., Druet P., Dosquet P. Natural autoantibodies in systemic lupus erythematosus // Clin. Exp. Immunol.-1987.-69.-P. $79-88$.

18.Bradford M. A rapid and sensitive method for quantitation and microgramm quantities of protein utilizing the principle of protein binding // Anal. Biochem.-1976.-72.-P. 193-200.

19.Kodama T., Fukui K., Kometani K. The initial phosphate bust in ATP hydrolysis by myosin and subfragment as studied by a modified malachite green method for determination of inorganic phosphate // J. Biochem.-1986. -99.-P. 1465-1472.

20.Целлариус Ю.Г., Семенова Л. А., Непомнящих Л. М. Очаговые повреждения и инфаркт миокарда: Световая, поляризационная и электронная микроскопия: Метод. разработка по патолог. анатомии.-Новосибирск, 1980.-72 с.

21.Mize R. R. Quantitative image analysis for immunocytochemistry and in situ hybridization // Neurosci. Meth. J.-1994.-54.-P. $219-237$.

22.Rose N., Bona C. Defining criteria for autoimmune diseases (Witebsky's postulates revisited) // Immunol. Today.-1993.-14.-P.

23.Caforio A. L. P., Bonifacio E., Stewart J. T., Neglia D., Parodi O., Bottazzo J. F., McKenna $W$. J. Novel organ-specific circulating cardiac autoantibodies in dilated cardiomyopathy // J. Amer. Chem. Soc.-1990.-15.-P. 1527-1534.

24.Hein S., Schaper J. The pathogenesis of dilated cardiomyopathy and heart failure: insights from cell morphology and biology // Curr. Opin. Cardiol.- 1996.-11.-P. 293-301.

25.Caforio A. L. P., Bonifacio E., Stewart J. T., Neglia D., Parodi O., Bottazzo J. F., McKenna W. J. Identification of a- and b-cardiac myosin heavy chain isoforms as major autoantigens in dilated cardiomyopathy // Circulation.-1992.-85.-P. 1734-1742.

26.Caforio A. L. P., Goldman J. H., Baig M. K., Haven A. J., Libera L. D., Keeling P. J., McKenna $W$. J. Cardiac autoantibodies in dilated cardiomyopathy become undetectable with disease progression // Heart.-1997.-77.-P. 62-67. 